\title{
NF-Y loss triggers p53 stabilization and apoptosis in HPV18- positive cells by affecting E6 transcription
}

\author{
Paolo Benatti ${ }^{1, *}$, Valentina Basile ${ }^{1, *}$, Diletta Dolfini ${ }^{2}$, Silvia Belluti ${ }^{1}$, Margherita \\ Tomei $^{1}{ }^{1}$, Carol Imbriano ${ }^{1}$ \\ ${ }^{1}$ Dipartimento di Scienze della Vita, Università di Modena e Reggio Emilia, 41125 Modena, Italy \\ ${ }^{2}$ Dipartimento di Bioscienze, Università degli Studi di Milano, 20133 Milano, Italy \\ *These authors have contributed equally to this work \\ Correspondence to: Carol Imbriano, email: cimbriano@unimo.it \\ Keywords: NF-Y, CCAAT-box, HPV18, p53, gene transcription
}

Abbreviations: Human Papilloma Virus, HPV; Transcription Factor, TF; Long Control Region, LCR; Upstream Regulatory Region, URR Received: November 10, 2015

Accepted: June 01, 2016

Published: June 13, 2016

\section{ABSTRACT}

The expression of the high risk HPV18 E6 and E7 oncogenic proteins induces the transformation of epithelial cells, through the disruption of p53 and Rb function. The binding of cellular transcription factors to cis-regulatory elements in the viral Upstream Regulatory Region (URR) stimulates E6/E7 transcription. Here, we demonstrate that the CCAAT-transcription factor NF-Y binds to a non-canonical motif within the URR and activates viral gene expression. In addition, NF-Y indirectly up-regulates HPV18 transcription through the transactivation of multiple cellular transcription factors. NFYA depletion inhibits the expression of E6 and E7 genes and re-establishes functional p53. The activation of p53 target genes in turn leads to apoptotic cell death. Finally, we show that NF-YA loss sensitizes HPV18-positive cells toward the DNA damaging agent Doxorubicin, via p53-mediated transcriptional response.

\section{INTRODUCTION}

The infection with high-risk human papillomavirus (HPV), usually of type 16 and 18 , is the main cause for cervical cancer $[1,2]$. In the course of cancer development, the HPV genome is frequently integrated into host-cell DNA. The open reading frame (ORF) of E2, $\mathrm{E} 4, \mathrm{E} 5$, and part of $\mathrm{L} 2$ genes are deleted after integration. Differently, the E6 and E7 early genes are preserved and encode for oncoproteins, which are responsible for initiation and progression of cervical cancer [2, 3]. E6 and E7 can independently immortalize human cells, but their cooperation results in a robust increase in transforming activity in most types of primary cells $[4,5]$. E7 interacts with and degrades retinoblastoma $(\mathrm{Rb})$, thus triggering E2F-dependent gene transcription of S-phase genes $[6,7]$. Prominent functions of E6 are the degradation of the oncosuppressor p53 [8] and the inhibition of its transcriptional activity [9]. In addition, E6 degrades the pro-apoptotic protein $\mathrm{BAX}$, leads to transcriptional activation of hTERT [10] and inhibits the degradation of SRC-family kinases [11].

The expression of E6 and E7 is transcriptionally controlled by specific elements within the viral Long
Control Region (LCR), also termed Upstream Regulatory Region (URR), a non-coding sequence between the ORFs of L1 and E6 genes. To date, only a handful of Transcription Factors (TFs) have been associated to positive regulation of HPV transcription, such as AP1, SP1, Oct1, YY1 and NF1 [12]. The TRANSFAC database revealed that other TFs could control HPV early gene expression, and ChIP assays detected FOXA1 and MYC binding to HPV18 URR [13]. More recently, ChIP-seq data from Hela-S3 cells have been re-analyzed to determine the occupancy of TFs on the integrated HPV18 genome [14]. Elk1, IRF3, MafK, MAZ, USF2 and ZKSCAN have been pointed out as possible HPV18 regulators.

The CCAAT sequence-specific transcription factor NF-Y activates the expression of multiple genes involved in cell proliferation [15]. NF-Y is composed of three subunits, NF-YA, NF-YB and NF-YC, whose association is necessary for DNA binding and transcriptional activity. A connection between NF-Y and p53 exists [16]. First, the inactivation of NF-YA, the regulatory subunit of the complex, triggers DNA damage and the activation of p53mediated apoptosis [17]. Second, NF-Y and p53 interaction is required for the repression of cell cycle CCAAT-genes following DNA damage (18-21). Finally, NF-YA is the 
target of PANDA, a p53-induced lncRNA involved in the regulation of apoptosis and senescence [22, 23].

Distinct effects were observed on cell cycle and gene transcription following NF-YA or NF-YB loss in wtp53-positive cells [17]. NF-YA knock-down suppresses cell growth by impairing $\mathrm{S}$ phase progression $[17,24]$. Replication defects are coupled with DNA damage response, p53 activation and apoptotic cell death. Differently, NF-YB inactivation triggers a delay in the G2/M progression without p53 activation, DNA damage response or overt apoptosis. Nevertheless, the GO term "apoptotic program" is significanly enriched in genes upregulated both by NF-YA and NF-YB knock-down [17].

Here, we show a new connection between NF-Y and p53 in HPV18+ cancer cells. NF-Y binds viral URR and transcriptionally induces HPV18 genes. By mutational analysis and Chromatin Immunoprecipitations (ChIPs), we identified a non-consensus NF-Y binding motif within the URR. NF-YA loss reduces the expression of E6 and E7 viral genes and results in the re-activation of a functional p53. This in turn triggers apoptotic cell death. Analysis of gene expression profiles in NF-YA-inactivated Hela cells indicates that NF-Y transactivates other key TFs driving the expression of viral genes. Finally, we show that NF-YA loss sensitizes Hela cells to Doxorubicin treatment.

\section{RESULTS}

\section{NF-YA loss induces p53 and apoptotic cell death in Hela cells}

We previously showed that p53-lacking HCT116 cells were less sensitive to apoptosis following NF-YA inactivation, compared to isogenic wt p53 cells [17]. In the course of that study, we noticed that NF-YA inactivation in Hela cells, which do not express p53 protein, led to a strong decrease in cell proliferation. Here we observed that SubG1 events raised from about 3\% in cells infected with scramble shRNA (SHC) to $16 \%$ upon NF-YA loss (shNF-YA) (Figures 1A and 1B). Cytofluorimetric analysis of AnnexinV staining confirmed that about $16 \%$ of shNF-YA cells were apoptotic, as observed in p53+ cells [17] (Figure 1C). Western Blot analysis of PARP1, whose cleavage is a hallmark of caspase-mediated apoptosis, further confirmed the activation of apoptosis (Figure 1D). We reasoned that NF-YA loss could re-activate p53, whose gene status is wt in Hela cells. Indeed, the expression of $\gamma \mathrm{H} 2 \mathrm{AX}$, marker of DNA damage response, and p53 increased in shNF-YA cells compared to control cells (Figure 1D). In order to rule out the possibility that off-target effects were causing the described effects, we used pooled shRNAs targeting different exons of NF-YA. p53 and apoptosis raised also in these experimental conditions (Supplementary Figure S1A). qRT-PCRs were performed to assess mRNA levels of p53. In shNF-YA cells, p53 transcription significantly increased, in opposition to
NF-Y-regulated cell cycle genes (Ccnb1, Ccnb2, Cdc2 and Top2A) (Figure 1E). Similarly, NF-YA inactivation resulted in activation of apoptosis and p53 re-expression in C4-I cell line, derived from a HPV18+ squamous cell carcinoma of the uterine cervix (Supplementary Figure S1B).

A functional p53 would be expected to drive expression of its own target genes: we therefore analyzed Affymetrix gene expression profiles, obtained after 72 hours from infections with scramble and NF-YA-targeting shRNAs [25]. 1492 genes were down-regulated and 1500 genes were up-regulated upon NF-YA loss, considering a threshold of 1.3-fold difference and a p-value smaller than 0.1 . We analyzed the affected promoters by pscan, a software for the identification of enriched TFBS (Transcription Factors Binding Sites) [26]. NF-Y sites were over-represented in down-regulated genes ( $\mathrm{p}$-value $=$ 2,41923E-14), indicating that NF-Y removal significantly decreased CCAAT-driven transcription (Figure 2A). Additional TFBS were found, hinting that NF-YA loss could inhibit the expression of genes regulated by other TFs. In agreement with this, we know that: i) NF-Y transcriptionally activates specific TFs, such as E2F1 and $\mathrm{Myc}$, and ii) a transcriptional partnership exists between NF-Y and other growth-controlling TFs [24, 25, 27-29]. KEGG analysis was performed with the three sets of up and down-regulated genes, and cell cycle was the major term identified in this cluster (Figure 2B), as already observed in HCT116 cells [17]. The NF-Y motif was less represented in activated genes ( $\mathrm{p}$-value $=9,96824 \mathrm{E}-05)$, suggesting that increased gene expression was at least in part due to indirect effects. Importantly, the terms p53 signaling pathway and apoptosis were identified as the major represented KEGG terms in shNF-YA cells. These data support the hypothesis that NF-YA abrogation triggers the activation of functional p53. The heat map in Figure $2 \mathrm{C}$ highlights the differential expression of p53-target genes upon NF-YA loss. These results were validated by qRT-PCRs on bona fide p53targets. The levels of Cdkn1a (p21 ${ }^{\text {Wafl/Cip1 }), ~ B a x, ~ P u m a ~}$ and the p53-dependent inducible Mdm2-P2, but not the p53-independent constitutive Mdm2-P1 transcript [30], significantly increased (Figure 3A). To verify whether p53 was functionally active, its association to regulatory regions of target genes was investigated by ChIP. A robust increase in $\mathrm{p} 53$ binding to the promoters of Cdkn1a, Mdm2-P2, Bax and Puma was induced by NF-YA depletion (Figure 3B).

Taken together, these results indicate that NF-YA inactivation in HPV18+ cells reactivates a functional p53, which in turn induces the expression of anti-proliferative and pro-apoptotic genes.

\section{NF-Y regulates the transcription of $\mathrm{HPV}$ oncogenic genes}

Altered regulation of the E6 gene could be the cause of p53 re-activation in NF-YA depleted cells. Western blot and qRT-PCR analysis showed a time-dependent decrease 
A

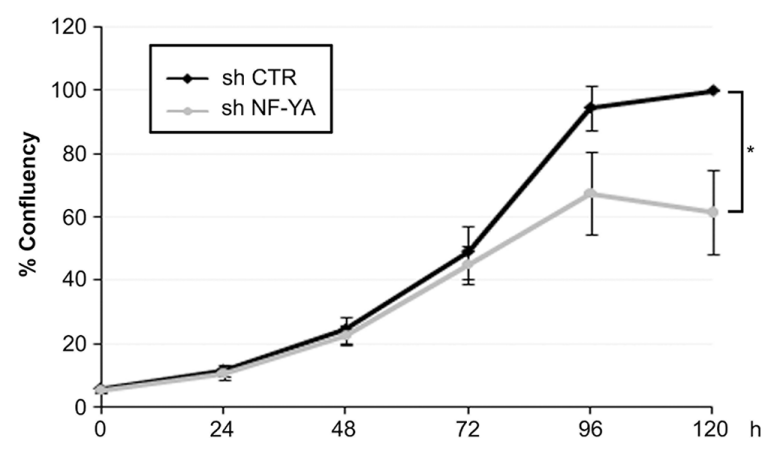

C

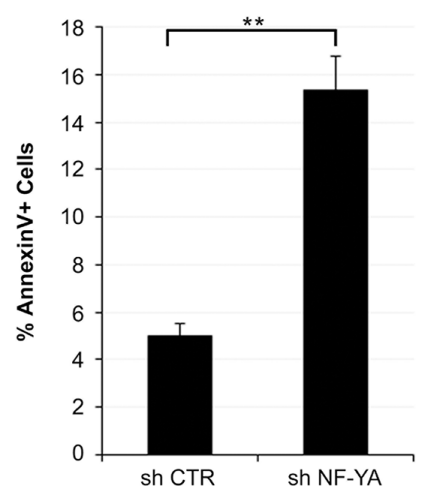

B

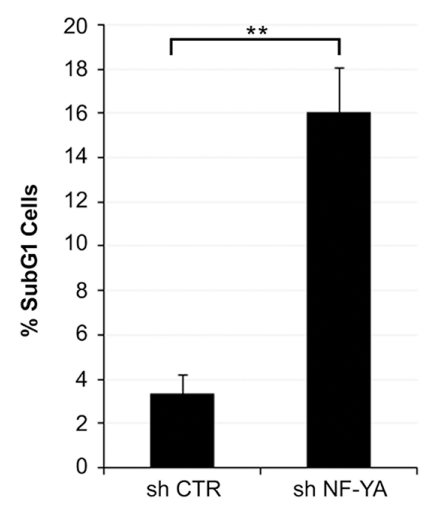

D

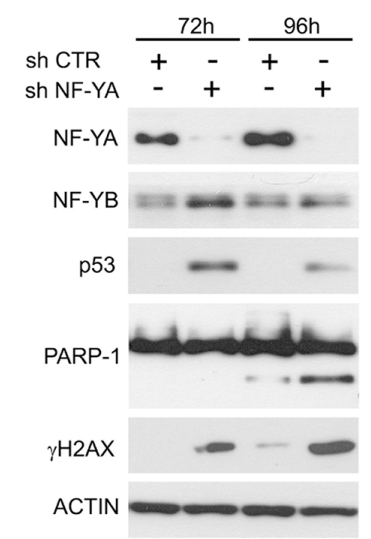

E

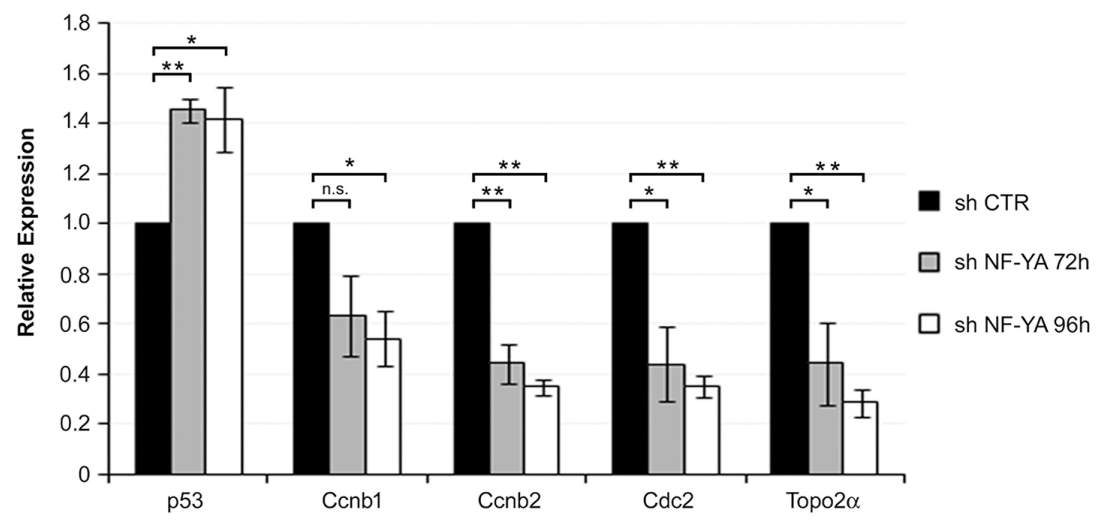

Figure 1: NF-YA inactivation in Hela cells triggers activation of apoptotic cell death and p53. A. Growing curve of Hela cells infected with shCTR and shNF-YA. Time points are indicated. Statistical significance was calculated with independent t-test at 120h $(* \mathrm{p}<0.05)$. B. Percentage of subG1 events determined by Propidium Iodide-FACS analysis of Hela cells 96h post infection with shCTR and shNF-YA lentiviral particles. Statistical significance was calculated with independent t-test $(* * p<0.01)$. C. Percentage of AnnexinV-positive cells $96 \mathrm{~h}$ post infection with shCTR and shNF-YA. Statistical significance was calculated with independent t-test $(* * \mathrm{p}<0.01)$. D. Expression levels of the indicated proteins in Hela whole cell extracts $72 \mathrm{~h}$ and $96 \mathrm{~h}$ post-infection with shCTR and shNF-YA. Actin was used as loading control. E. q-RT PCR analysis of the indicated transcripts $72 \mathrm{~h}$ and $96 \mathrm{~h}$ post-infection with shCTR and shNF-YA. The housekeeping hRpl19 gene has been used for normalization. Statistical significance is calculated with independent t-test $(* \mathrm{p}<0.05 ; * * \mathrm{p}<0.01)$. Error bars indicate Standard Error of the Mean (SEM). 
in E6 levels following NF-YA inactivation in Hela and C4-1 cells (Figure 4A, 4B and Supplementary Figure $\mathrm{S} 1 \mathrm{C}, \mathrm{S} 1 \mathrm{~F})$. We detected a similar decrease in E7 mRNA expression, which is also controlled by the URR.

Genomic analysis identified two putative NF-Y binding sites within the URR: the first, at $-394 \mathrm{bp}$ from the TSS, is an inverted CCAAT (ATTGG) sequence, conserved in both African (Af) and non-African (non-Af) HPV18 lineages [31] The second one, at $-232 \mathrm{bp}$, is represented by a canonical ATTGG motif in the Af and non-canonical CTTGG sequence in the non-Af lineage (Supplementary Figure S2). To assess gene expression driven by URR, we used the HPV18-URR pGL3Luciferase reporter plasmid, which contains the upstream
A

\begin{tabular}{|l|l|l|l|}
\hline \multicolumn{1}{|c|}{ TF NAME } & \multicolumn{1}{|c|}{ MATRIX ID } & \multicolumn{1}{|c|}{ Z SCORE } & \multicolumn{1}{c|}{ P VALUE } \\
\hline Egr1 & MA0162.1 & 10,6424 & $9,78002 \mathrm{E}-28$ \\
TFAP2A & MA0003.1 & 10,3581 & $3,15939 \mathrm{E}-26$ \\
E2F1 & MA0024.1 & 9,99958 & $6,50683 \mathrm{E}-25$ \\
SP1 & MA0079.2 & 10,0205 & $9,07272 \mathrm{E}-25$ \\
KIf4 & MA0039.2 & 9,44262 & $3,1022 \mathrm{E}-22$ \\
HIF1A::ARNT & MA0259.1 & 9,07141 & $9,49191 \mathrm{E}-21$ \\
Mycn & MA0104.2 & 8,42678 & $3,03011 \mathrm{E}-18$ \\
PAX5 & MA0014.1 & 8,16189 & $3,12499 \mathrm{E}-17$ \\
Zfx & MA0146.1 & 8,1871 & $3,21718 \mathrm{E}-17$ \\
GABPA & MA0062.2 & 7,79786 & $6,88526 \mathrm{E}-16$ \\
Arnt & MA0004.1 & 7,51873 & $5,10841 \mathrm{E}-15$ \\
Myc & MA0147.1 & 7,38521 & $1,8694 \mathrm{E}-14$ \\
NF-YA & MA0060.1 & 7,29561 & $\mathbf{2 , 4 1 9 2 3 E - 1 4}$ \\
MIZF & MA0131.1 & 6,95387 & $5,5309 \mathrm{E}-13$ \\
PLAG1 & MA0163.1 & 6,69614 & $3,97564 \mathrm{E}-12$ \\
ELK4 & MA0076.1 & 6,399 & $2,63457 \mathrm{E}-11$ \\
ELK1 & MA0028.1 & 6,25985 & $6,54767 \mathrm{E}-11$ \\
\hline
\end{tabular}

B

UP-REGULATED
\begin{tabular}{|c|c|}
\hline KEGG.term & P VALUE \\
\hline p53 signaling pathway & $9.78 \mathrm{E}-10$ \\
\hline Apoptosis & $8.35 \mathrm{E}-06$ \\
\hline $\begin{array}{c}\text { Valine, leucine and isoleucine } \\
\text { degradation }\end{array}$ & $1.61 \mathrm{E}-05$ \\
\hline
\end{tabular}

DOWN-REGULATED

\begin{tabular}{|c|c|}
\hline KEGG.term & P VALUE \\
\hline Cell cycle & $4.82 \mathrm{E}-09$ \\
\hline Oocyte meiosis & $6.95 \mathrm{E}-07$ \\
\hline Pathogenic Escherichia coli infection & $1.04 \mathrm{E}-05$ \\
\hline RNA transport & $1.15 \mathrm{E}-05$ \\
\hline Gap junction & $1.25 \mathrm{E}-05$ \\
\hline Ribosome biogenesis in eukaryotes & $2.41 \mathrm{E}-05$ \\
\hline $\begin{array}{c}\text { N-Glycan biosynthesis } \\
\text { Arginine and proline metabolism }\end{array}$ & $1.43 \mathrm{E}-04$ \\
\hline $\begin{array}{c}\text { Progesterone-mediated oocyte } \\
\text { maturation }\end{array}$ & $5.99 \mathrm{E}-04$ \\
\hline
\end{tabular}

C

\begin{tabular}{|c|c|}
\hline \multirow{2}{*}{$\begin{array}{c}\text { GENE } \\
\text { CDKN1A }\end{array}$} & $\mathrm{HeLa}$ \\
\hline & \\
\hline \multicolumn{2}{|l|}{ ZMAT3 } \\
\hline \multicolumn{2}{|l|}{ CCNG2 } \\
\hline \multicolumn{2}{|l|}{ MDM2 } \\
\hline \multicolumn{2}{|l|}{ DDB2 } \\
\hline \multicolumn{2}{|l|}{ RRM2B } \\
\hline \multicolumn{2}{|l|}{ FAS } \\
\hline \multicolumn{2}{|l|}{ SESN1 } \\
\hline \multicolumn{2}{|l|}{ CDK6 } \\
\hline \multicolumn{2}{|l|}{ TP53 } \\
\hline \multicolumn{2}{|l|}{ CASP8 } \\
\hline \multicolumn{2}{|l|}{ CASP3 } \\
\hline \multicolumn{2}{|l|}{ APAF1 } \\
\hline \multicolumn{2}{|l|}{ CCNG1 } \\
\hline PPM1D & \\
\hline ATM & \\
\hline BAX & \\
\hline TNFRSF10B & \\
\hline TP5313 & \\
\hline SESN2 & \\
\hline $\mathrm{BBC} 3$ & \\
\hline IGFBP3 & \\
\hline CHEK2 & \\
\hline PERP & \\
\hline SESN3 & \\
\hline SERPINB5 & \\
\hline SFN & \\
\hline CDK4 & \\
\hline CASP9 & \\
\hline RFWD2 & \\
\hline CCND3 & \\
\hline MDM4 & \\
\hline PIDD & \\
\hline TP53AIP1 & \\
\hline IGF1 & \\
\hline CD82 & \\
\hline CCND2 & \\
\hline BAl1 & \\
\hline CCNB3 & \\
\hline $\mathrm{El} 24$ & \\
\hline TSC2 & \\
\hline GADD45A & \\
\hline ATR & \\
\hline SHISA5 & \\
\hline RCHY1 & \\
\hline CCNE2 & \\
\hline SIAH1 & \\
\hline THBS1 & \\
\hline TP73 & \\
\hline GADD45G & \\
\hline CHEK1 & \\
\hline GADD45B & \\
\hline CCNE1 & \\
\hline STEAP & \\
\hline CCNB1 & \\
\hline PMAIP1 & \\
\hline CDK2 & \\
\hline CDKN2A & \\
\hline BID & \\
\hline RPRM & \\
\hline CDK1 & \\
\hline CCNB2 & \\
\hline RRM2 & \\
\hline CCND1 & \\
\hline CYCS & \\
\hline PTEN & \\
\hline SERPINE1 & \\
\hline GTSE1 & \\
\hline
\end{tabular}

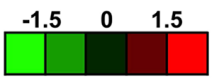

Figure 2: NF-YA loss activates a p53-dependent transcriptional response. A. Pscan analysis of Transcription Factors Binding Sites (TFBS) with relative p-values in down-regulated genes following NF-YA inactivation by shRNA. B. KEGG analysis of up- and down-regulated genes retrieved from gene expression profiles of NF-YA-inactivated cells. C. Heat map of p53-target genes upon NF-YA abrogation. 
ATTGG and the downstream CTTGG sequences [32]. NF-YA inactivation significantly reduced HPV18-URRLuc activity, with respect to control cells (Figure 4C). Thereafter, we mutated the -394 element either in the core ATTGG -to ATGTG (mut1) or CGGTT (mut2)- or in the flanking nucleotides on both the 5' and 3 ' ends (mut3), potentially improving the quality of the putative binding site [33]. We also mutated the $-232 \mathrm{bp}$ element from CTTGG to CGGTT (mut4). These constructs were transfected in Hela cells: reporter activity of mut 1 or mut2 was not reduced, and mutations of the flanking regions marginally enhanced HPV18 activity. Differently, the activity of mut4 was substantially reduced (Figure 4D). NF-YA loss decreased mut4-Luc activity (Figure 4E),

A

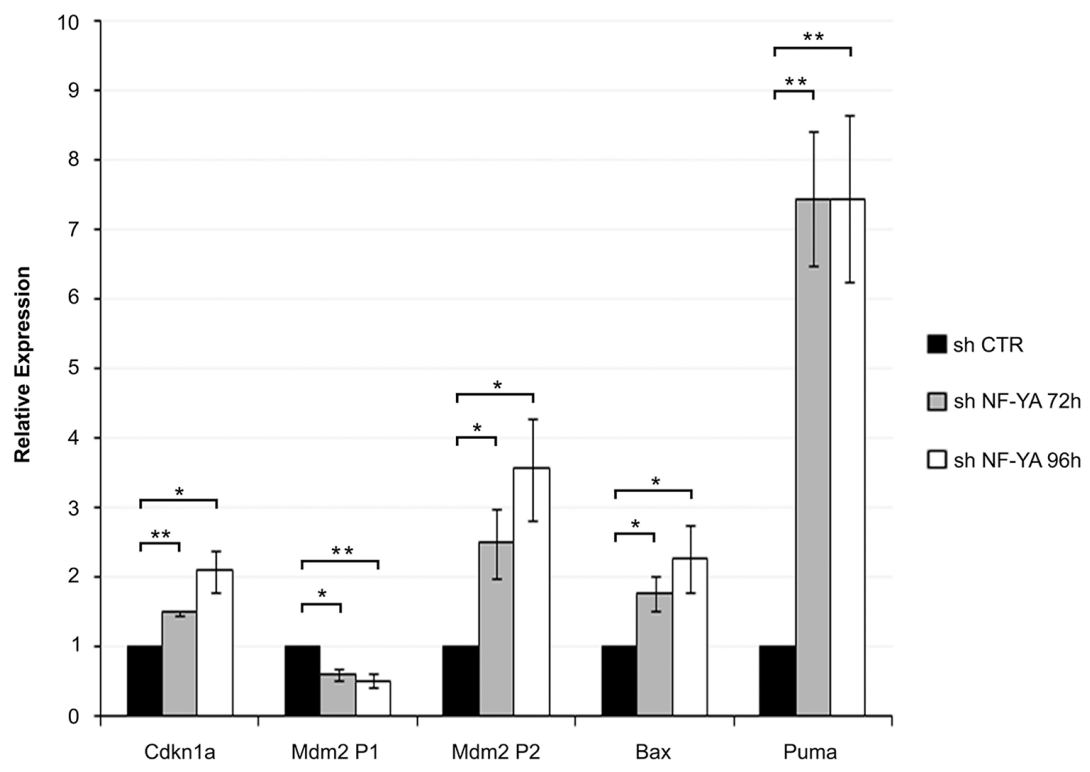

B

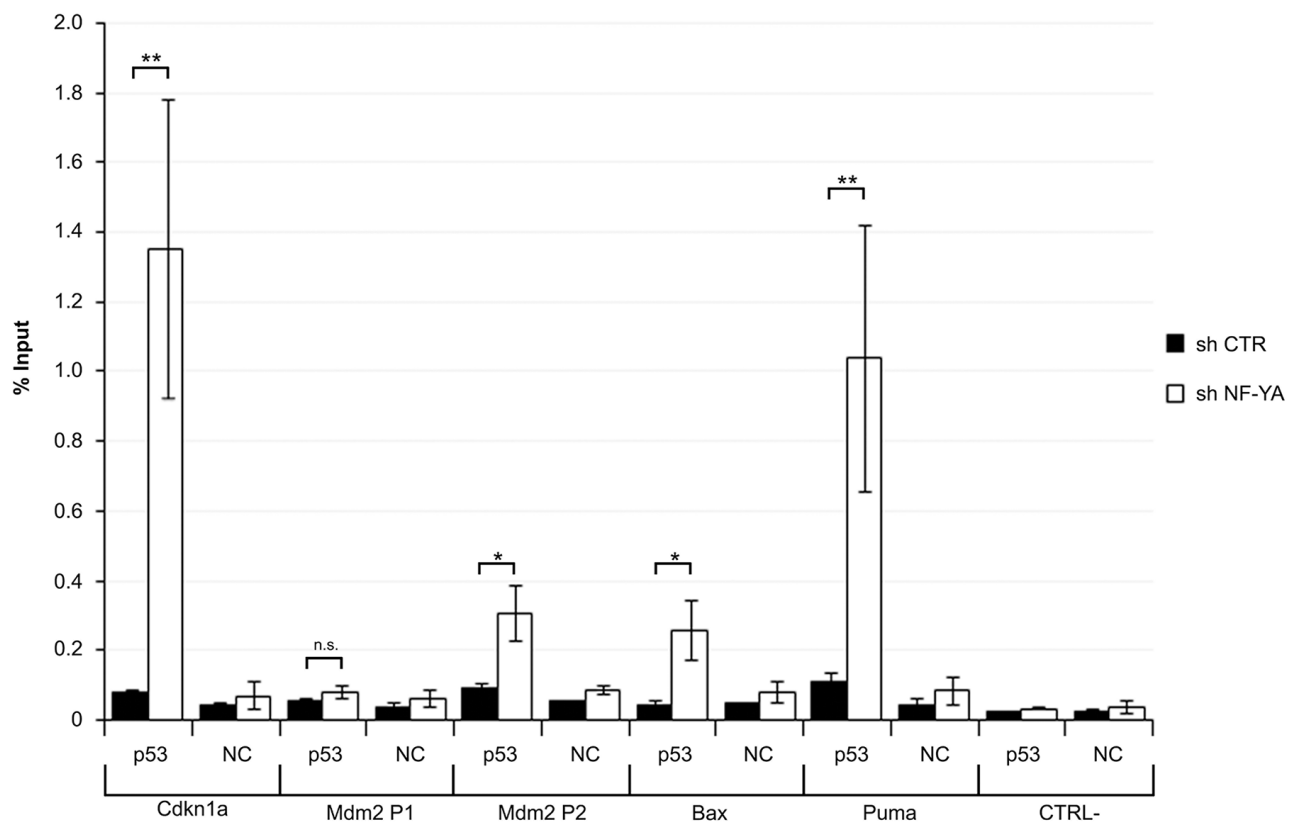

Figure 3: Activation of functionally active p53 in NF-YA-inactivated Hela cells. A. qRT-PCR analysis of bona fide p53 target genes $72 \mathrm{~h}$ and $96 \mathrm{~h}$ post-infection with shCTR and shNF-YA. Amplified genes are indicated. Statistical significance was calculated with independent t-test $(* \mathrm{p}<0.05$; ** $\mathrm{p}<0.01)$. B. ChIP analysis of $\mathrm{p} 53$ binding to the regulatory regions of Cdkn1a, Mdm2-P1, Mdm2-P2, Bax and Puma genes in shCTR and shNF-YA cells $96 \mathrm{~h}$ after infection. CTRL- represents a CCAAT-less negative control region, localized at about 5000bp upstream of the Myc gene. The p53 enrichment was determined as percentage of IP recovery. Statistical significance was calculated with independent t-test $(* \mathrm{p}<0.05 ; * * \mathrm{p}<0.01)$. Error bars indicate SEM. 
A

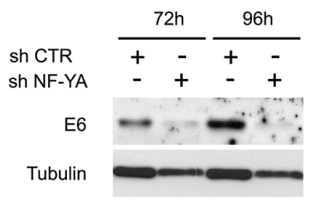

C
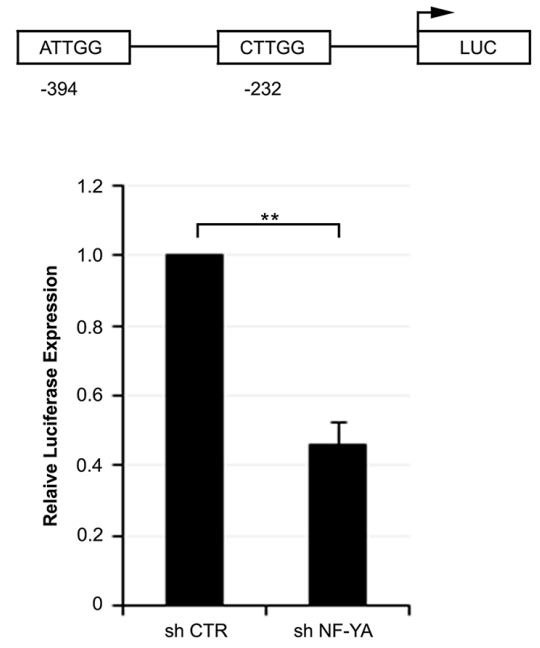

$\mathrm{E}$

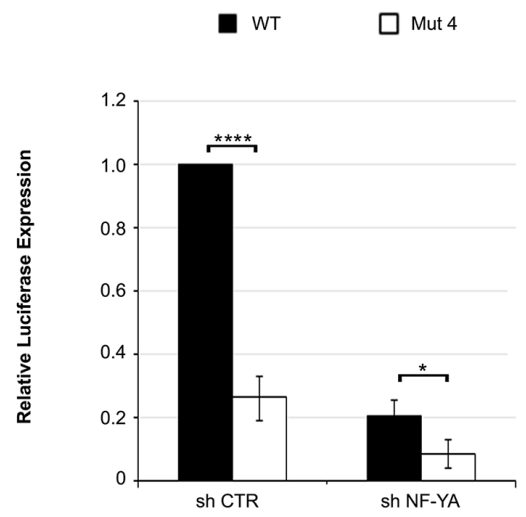

B

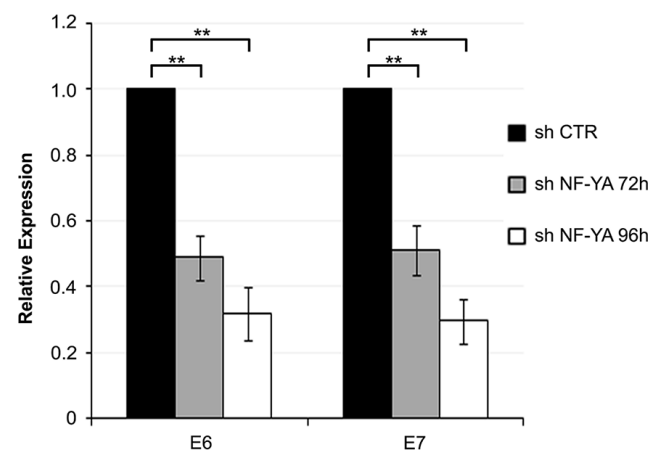

D

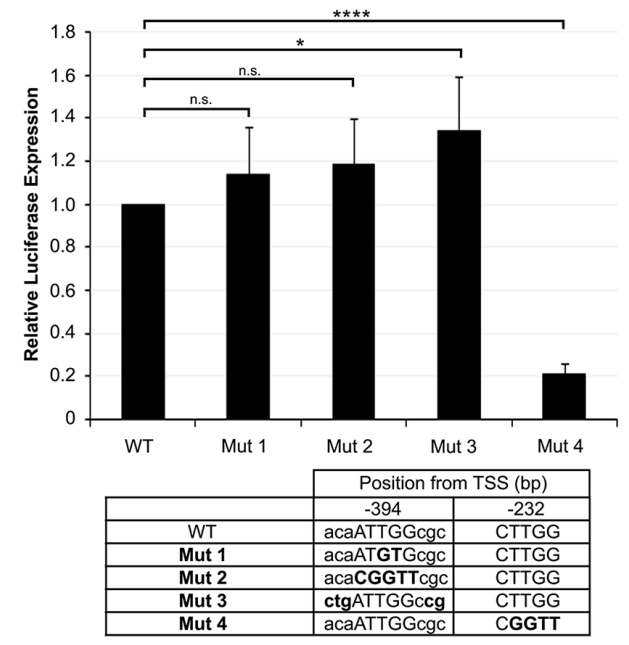

$\mathrm{F}$
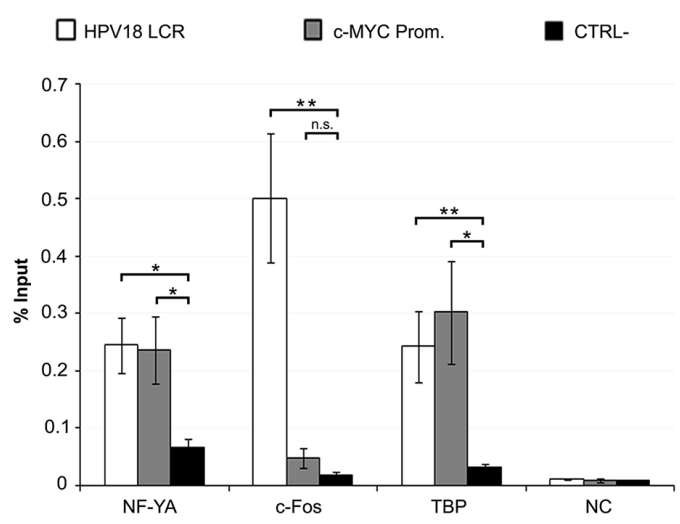

Figure 4: NF-Y transcriptionally controls the expression of HPV18-URR driven genes. A. Western Blot analysis of E6 protein in whole cell extracts from Hela infected with shCTR and shNF-YA for 72h and 96h. Tubulin was used as loading control. B. Relative expression levels of E6/E7 genes normalized to the hRp119 transcript in shNF-YA cells versus shCTR, arbitrarily set at 1 . Statistical significance was determined with independent t-test $(* * \mathrm{p}<0.01)$. C. Upper panel: schematic representation of CCAAT boxes position in HPV18-URR, cloned upstream of the luciferase (LUC) reporter gene. Lower panel: relative HPV18-URR-driven luciferase activity in shCTR and shNF-YA cells. Statistical significance was calculated with independent t-test $(* * \mathrm{p}<0.01)$. D. Relative luciferase expression of mutant promoters with respect to wt HPV18 promoter. Statistical significance was calculated with independent t-test $(* \mathrm{p}<0.05 ; * * * * \mathrm{p}$ $<0.0001)$. The table indicates the position and sequence of the two wt and mutated NF-Y-motives. E. Relative luciferase activity of wt and mut4 HPV18 URR in shCTR and shNF-YA cells. F. ChIP analysis of NF-YA, c-FOS and TBP binding to HPV18-LCR, c-Myc promoter and negative control region (CTRL-) in Hela cells. Enrichment was calculated as percentage of IP recovery. Statistical significance was calculated with independent t-test between promoters of interest and CTRL- region $(* \mathrm{p}<0.05 ; * * \mathrm{p}<0.01)$. Error bars indicate SEM. 
hinting at NF-Y indirect mechanisms occurring in URR regulation.

Having established the functionality of a CCAATlike DNA element, we wished to ascertain whether the role of NF-Y on HPV18 transcription was direct. Analysis of Hela-S3 ENCODE ChIP-Seq data scored negative in the HPV18 genome area, either for NF-YA or NF-YB [14]. Nevertheless, we decided to perform qChIPs in Hela cells with anti-NF-YA antibody (Figure 4F). A significant enrichment in NF-YA binding to HPV18-LCR was observed over control IgG, similar to the levels found in the human Myc CCAAT-promoter bound by NF-Y [24]. As positive controls, the same viral region showed binding of FOS and TBP, known to associate to HPV18-LCR [14]. All together, these results suggest that NF-Y directly affects HPV18 transcription by binding to a non-canonical CCAAT element within the URR region.

\section{NF-YA inactivation affects the expression of TFs involved in HPV18 transcription}

We next wondered whether NF-Y could be involved in the regulation of other TFs identified as regulators of viral genes. AP1 (Jun/Fos), E2F1, SP1, Myc and Elk1 are associated to HPV18-LCR by ChIP-seq analysis [14], and some of them are indispensable for viral gene expression [12, 34, 35]. Jun, JunB and Fos, members of the AP1 complex, E2F1, Myc, Elk1 and SP1 were indeed down-regulated at the transcriptional level following NF-YA inactivation in Hela cells (Figure 5A). Western blot analysis showed a decrease in protein levels as well (Figure 5B). With the exception of Fos, all the other TFs have canonical NF-Y-motives within their regulatory regions. Consequently, we checked whether NF-Y could function as direct transcriptional regulator. ENCODE data from Hela-S3 ChIP-seq are positive for NF-Y binding in all of the analyzed genes, Fos excluded (Figure 5C). Thus, in addition to a direct role, NF-Y could indirectly induce HPV18 transcription through the transactivation of TFs that cooperate in viral transcription.

\section{NF-YA loss sensitizes cells to Doxorubicin- induced cell death}

We then investigated whether p53 activation via shNF-YA could sensitize HPV18+ cells toward DNAdamaging agents. Hela cells were insensitive to $0.1 \mu \mathrm{M}$ Doxorubicin (Doxo), a DNA intercalator used in clinics for a broad spectrum of tumors. Indeed, p53 expression and apoptosis did not increase in Doxo versus control cells (Supplementary Figure S3). Untreated and Doxotreated cells were infected with shRNA lentiviral particles at low MOI, in order to lower NF-YA expression without inducing strong apoptotic cell death (subG1 4\% in shNFYA untreated cells) (Figure 6A). The concurrent treatment with Doxo and shNF-YA (shNF-YA+Doxo cells) activated an evident cell death response (subG1 16\%). Consistently, the expression levels of p53, p21 and cleaved-PARP1 increased in shNF-YA+Doxo cells (Figure 6B). qRTPCRs showed a significant increase in the levels of p53target genes in shNF-YA+Doxo cells, compared to both single treatments (shCTR+Doxo and shNF-YA+DMSO) (Figure 6C). Differently, no synergistic effect was observed on the transcriptional activation of Bax. The expression of NF-YA, E6 and E7 genes decreased following NF-YA loss, as expected, and did not change upon Doxo administration. p53 knock-down in NF-YA-inactivated cells significantly reduced SubG1 events triggered by Doxo treatment (Figure $6 \mathrm{D}, 6 \mathrm{E})$. Consistently with p53 loss, the transcription levels of p53-target genes decreased (Figure 6F).

In summary, even incomplete ablation of NF-YA leads to increased sensitivity to a DNA-damaging agent, via activation of a p53-mediated transcriptional response.

\section{DISCUSSION}

Our study shows that the abrogation of NF-YA triggers p53-mediated apoptosis in HPV18+ cells. We demonstrate that NF-Y is a transcriptional activator of HPV18-URR gene expression by binding to a noncanonical inverted CCAAT box, located at $-232 \mathrm{bp}$ from the TSS. Interestingly, this NF-Y-bound sequence (CTTGG) partially overlaps with a previously identified NF1 binding site (TTGGCT) (Supplementary Figure S4). Coherently with our results, mutation of the NF1 site, that abolishes NF1 binding but preserves the NF-Y motif (CTTGGta), does not reduce the activity of HPV18 URR in Hela cells [36]. This hints at a predominant role of NF-Y within these two overlapping TFBS.

HPV high risk types 16 and 18 share some common transcriptional regulators, such as SP1 and AP1 [12]. Nevertheless, neither canonical NF-Y motives nor the non-conserved element here described were identified in HPV16 URR (Supplementary Figure S4).

The restoration of active p53 can be achieved in HPV18+ cells through pharmacological treatments, such as Celecoxib or the combination of Actinomycin D with Leptomycin B [37, 38]. Also the targeting of TFs involved in HPV transcriptional regulation, such as NF90/NF45 [39, 40], has been used as p53-activating strategy. We established here that NF-Y targeting reactivates functional p53 as well. Note that NF-Y inactivation induces p53 post-translational modifications $[17,41]$ and reduces the basal expression of CCAAT box-containing proteasome genes [42]. Therefore, it is likely that these mechanisms can cooperate with E6 down-regulation to restore functional p53 upon NF-YA loss.

We also investigated the effects of NF-YA abrogation on other p53 family members, p63 and p73. The level of p63 mRNA, already low in Hela control cells, was further reduced following NF-YA loss. At the protein level, we observed a decrease in $\Delta \mathrm{Np} 63$, the only isoform we detected by Western blot in control cells (Supplementary 
Figure S5) [43, 44]. This result is consistent with the established role of NF-Y as transcriptional activator of the $\Delta \mathrm{Np} 63$ promoter [45]. Also p73 mRNA levels were lowered by shNF-YA infection, presumably as a consequence of reduced expression of E2F1, known p73 transcriptional activator [46] (Supplementary Figure S5).

NF-Y plays an important role in the transcriptional control of genes encoded by the genome of different viruses, such as the human Herpes Simplex Virus type 1 (HSV-1) [47], the Epstein Barr Virus (EBV) [48], the Kaposi's sarcoma-associated herpesvirus (KSHV) [49] and the Minute Virus of Mice (MVM) [50]. The transcriptional control of the MVM P4 promoter is determined by the association of NF-Y to an unusual site -CCAAC-, similarly to what we described here. The atypical NF-Y motif found in the non-Af lineage is functional, presumably thanks to nucleotides on both the 5' and 3' flanking sides. Since a canonical inverted CCAAT box is present in Af, it is likely that the $-232 \mathrm{bp}$ element has preserved its transcriptional function in both lineages. In general, NF-Y requires a perfect match of the pentanucleotide, as well as flanking sequences, for efficient DNA-binding [51]. However, the 3D structure of the NF-Y complex bound to CCAAT indicates that the final $\mathrm{T}$ is the only nucleotide of CCAAT not contacted in a sequence-specific way by NF-YA [52]. This suggests that a higher degree of tolerance is allowed at this position. Moreover, ChIP-Seq data clearly recovered a vast majority of CCAAT-containing locations $(>80 \%)$, but non canonical sites usually have a different nucleotide instead of the final $\mathrm{T}$ [25].

The inhibition of the interactions of NF-Y to its binding site through DNA sequence-specific conjugated polyamides is a successful strategy to affect the transcription of specific CCAAT-promoters [53-55]. It is therefore tempting to speculate that drug specific inhibition of NF-Y association to its binding site in HPV18-URR could represent and interesting therapeutic strategy against HPV+ cancer cells.

In summary, our results identify an additional mechanism through which NF-Y and p53 are connected in $\mathrm{HPV}+$ cancer cells (Figure 7). NF-YA inactivation might represent an interesting anti-tumor strategy to induce apoptosis in high-risk HPV infected cancer cells, or to sensitize them to conventional anti-tumor drugs, through the re-establishment of p53-mediated cell death.

A

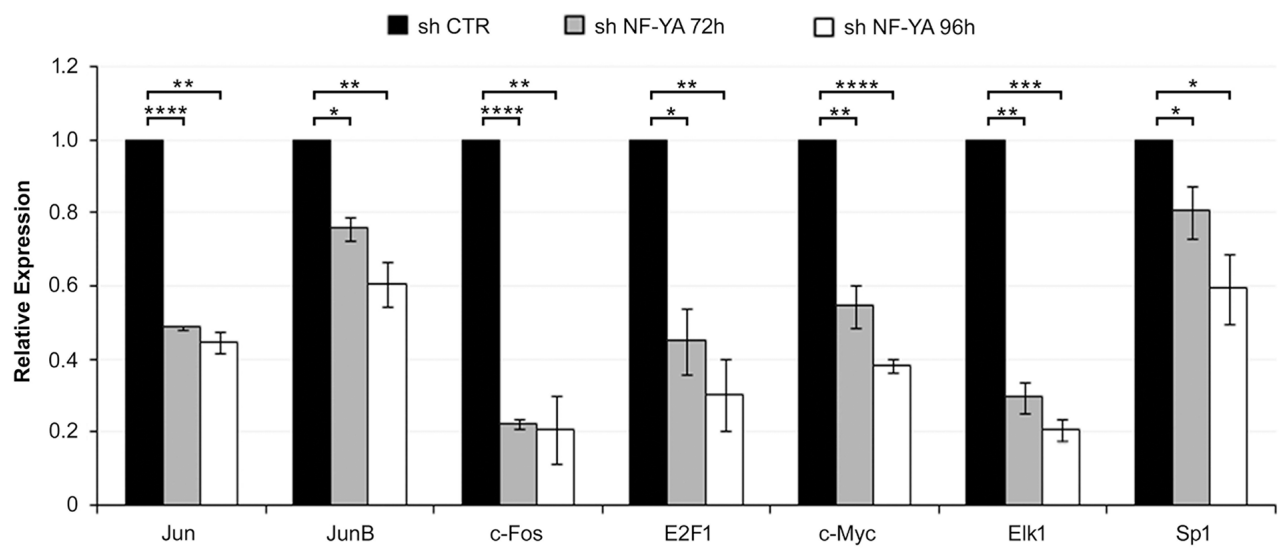

B

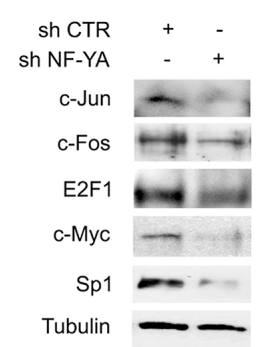

C

\begin{tabular}{|l|c|c|l|l|}
\hline Transcription Factors & Microarray & qRT-PCR & ChIP-seq NF-Y Binding & CCAAT(-500 TSS) \\
\hline Jun & Down & Down & + & + \\
\hline JunB & Unchanged & Down & + & + \\
\hline C-Fos & Unchanged & Down & - & - \\
\hline E2F1 & Unchanged & Down & + & + \\
\hline C-Myc & Down & Down & + & + \\
\hline Elk1 & Down & Down & + & + \\
\hline Sp1 & Unchanged & Down & + & + \\
\hline
\end{tabular}

Figure 5: NF-YA inactivation affects the expression of key transcription factors regulating HPV18-URR activity. A. qRT-PCR analysis of the indicated genes $72 \mathrm{~h}$ and $96 \mathrm{~h}$ post-infection with shCTR and shNF-YA. hRpl19 has been used as reference gene. Statistical significance was calculated with independent t-test $(* \mathrm{p}<0.05 ; * * \mathrm{p}<0.01 ; * * * \mathrm{p}<0.001 ; * * * * \mathrm{p}<0.0001)$. Error bars indicate SEM. B. Western blot analysis of the indicated proteins in shCTR and shNF-YA cells 96h post-infection. C. The table indicates the effect of NF-YA loss on gene transcription of the indicated transcription factor (TF), observed by qRT-PCR and gene expression profiling, the binding of NF-Y (ENCODE ChIP-seq data) and the presence (+) or not (-) of canonical NF-Y binding site in TF-promoters $(-500 \mathrm{bp}$ from the TSS). 
A

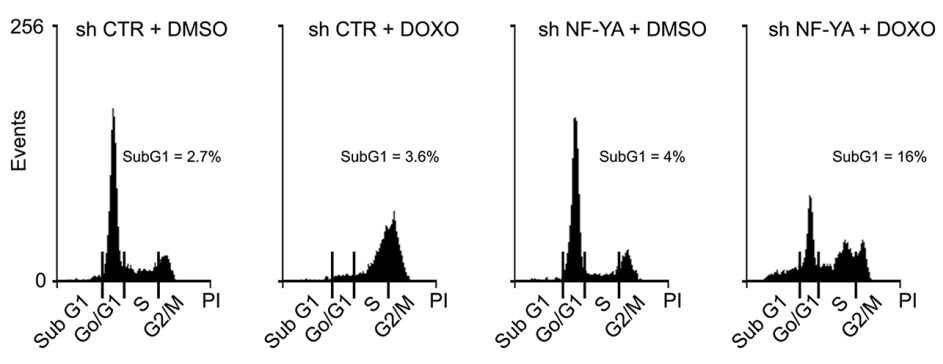

B

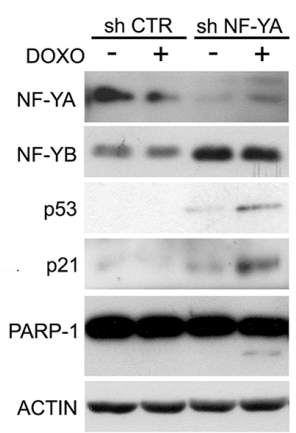

C

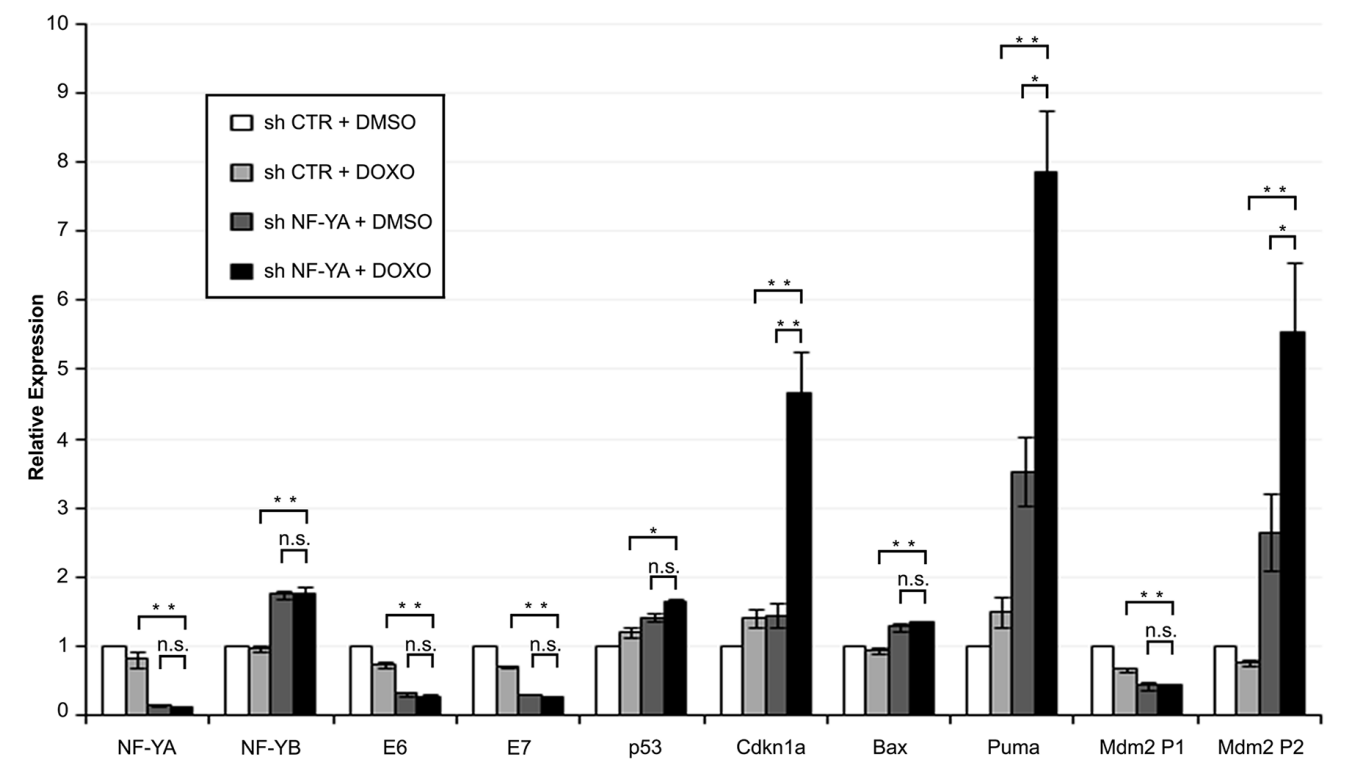

D

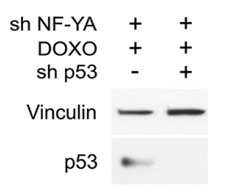

$\mathrm{E}$

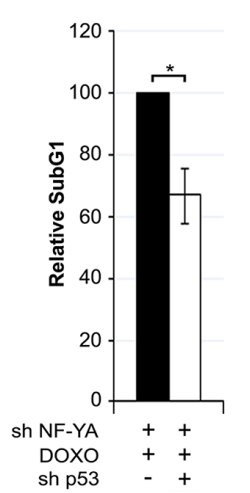

$\mathrm{F}$

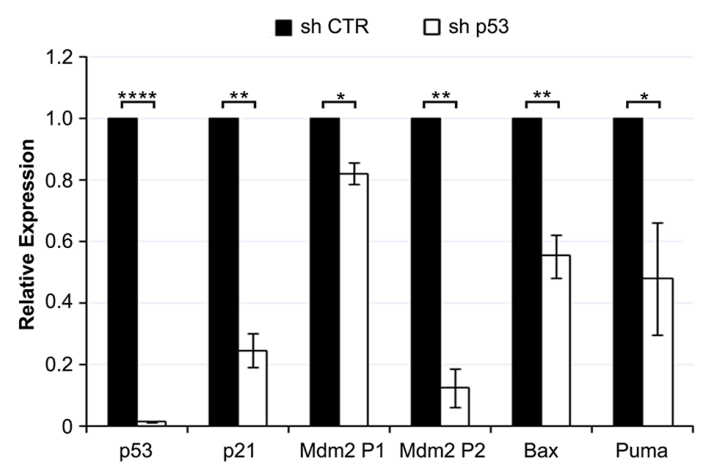

Figure 6: NF-YA loss sensitizes Hela cells to Doxorubicin-induced p53-dependent cell death. A. DNA distribution analysis of Propidium Iodide-stained Hela cells infected with shCTR and shNF-YA for $72 \mathrm{~h}$ and then treated with DMSO or $0.1 \mu$ M Doxorubicin (DOXO). The percentages of SubG1 events are indicated. Shown images are representative of three independent experiments. B. Western blot analysis of whole cell extracts in the experimental conditions described above. Antibodies are indicated. Actin was used as loading control. C. qRT-PCR relative expression analysis of p53 target genes in shCTR and shNF-YA cells treated or not with DOXO. The housekeeping hRpl19 gene has been used for normalization. The expression levels of control cells (shCTR +DMSO) have been arbitrarily set at 1. D. p53 expression levels in NF-YA-inactivated cells infected with shCTR and shp53 and treated with DOXO. E. Effects of p53 loss (shp53) on SubG1 events in NF-YA-inactivated cells treated with DOXO. The percentage of SubG1 in NF-YA-inactivated cells infected with shCTR has been arbitrarily set at 100\%. F. qRT-PCR analysis of the indicated transcripts in NF-YA/p53 double knocked down cells versus NF-YA-inactivated cells (set at 1), following DOXO treatment. Statistical significance was calculated with independent t-test $(* \mathrm{p}<$ $0.05 ; * * \mathrm{p}<0.01 ; * * * * \mathrm{p}<0.0001 ;$ ). Error bars indicate SEM. 

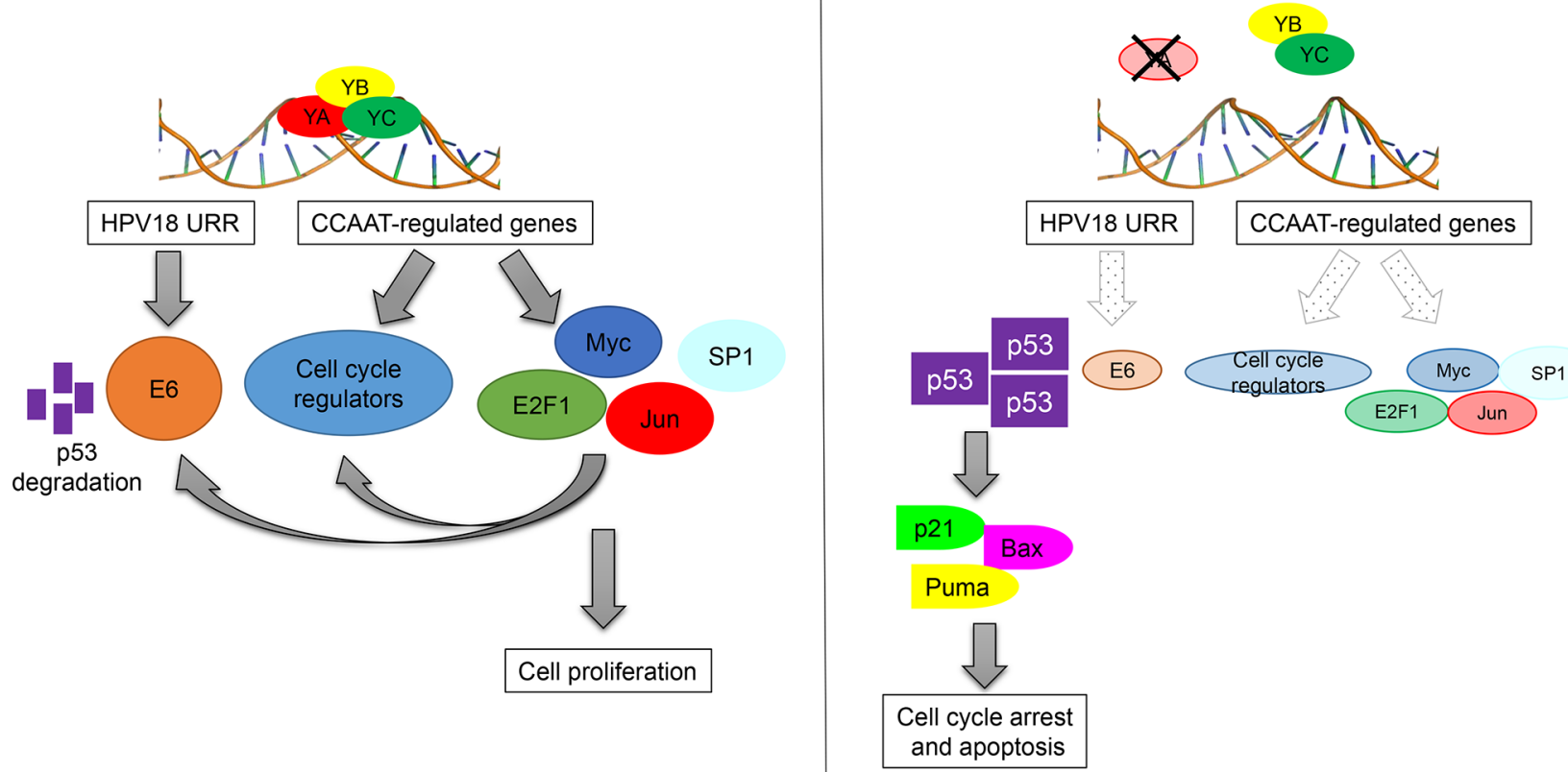

Figure 7: Schematic representation of direct and indirect functions of NF-Y in the control of HPV18+ cells proliferation.

\section{MATERIALS AND METHODS}

\section{Cell culture, treatments and shRNA inactivation}

The cervical cancer Hela and C4-I HPV18+ cell lines were maintained in complete Dulbecco's Modified Eagle's Medium (DMEM) with 10\% Foetal Bovine Serum (FBS) and grown at $37^{\circ} \mathrm{C}$ in a humidified incubator containing 5\% CO2 [56]. Doxorubicin (Sigma Aldrich) was solved in DMSO and added to the cells at the indicated concentrations for 24 hours.

Hela and C4-I cells were infected with PLKO1 shRNA NF-YA (targeting exon 6) lentiviral particles $(\mathrm{MOI}=8)$, as previously described $[17,25]$. A combination of two different PLKO1 shRNAs (Sigma Aldrich) targeting exons 8 and 10 of NF-YA was used (MOI=6 for each shRNA) (Supplementary Figure S1A). p53 inactivation was achieved by infecting cells with PLKO1 p53-targeting shRNA (Addgene, \#19119) (MOI=8). The puromycin resistance cassette was replaced with the EGFP cassette, as previously described [17].

\section{Cell proliferation analysis}

10.000 cells have been seeded into 24-well plates and infected shCTR and shNF-YA lentiviral particles. At the indicated time points, cells have been fixed with Crystal Violet solution $(0.25 \%$ Crystal Violet, $20 \%$ methanol in water) for $1 \mathrm{~h}$ and then washed 6 times with water. Cell layers have been than resuspended in $1 \mathrm{ml}$ of acid isopropanol $(\mathrm{HCl} 0.1 \mathrm{M}, 20 \%$ isoprophanol) and the adsorbed Crystal Violet has been quantified with spectrophotometer at a $\lambda$ of $540 \mathrm{~nm}$.

\section{Flow cytometry}

For the determination of cell cycle progression, cells were stained with Propidium Iodide (PI), as previously described [57]. Apoptotic cells were detected by FACS using Annexin V-PE conjugate (BD Biosciences, Becton Dickinson Italia, Milan, Italy), following the protocol of the manufacturer.

\section{Immunoblotting}

For whole cell lysates, cells were resuspended in $1 \mathrm{X}$ SDS sample buffer $(25 \mathrm{mM}$ Tris- $\mathrm{HCl} \mathrm{pH} 6.8,1.5 \mathrm{mM}$ EDTA, 20\% glycerol, 2\% SDS, 5\% b-mercaptoethanol, $0.0025 \%$ Bromophenol blue). For Western blot analysis, equal quantity of cell lysates were separated by SDSpolyacrylamide gel electrophoresis, transferred to PVDF membrane (VWR) and probed with the following primary antibodies: anti-NF-YA (Santa Cruz, sc-17753), antiNF-YB (GeneSpin), anti-p53 (Santa Cruz, sc-126), antiPARP1 (Santa Cruz, sc-8007), anti-H2AX (Santa Cruz, sc101696), anti-p21 (Millipore, 05-345), anti-E2F1 (Bethyl, A300-766A), anti-cJun (Bethyl, A302-958A), anti-cMyc (Santa Cruz, sc-764), anti-Fos (Santa Cruz, sc-52), anti-p63 4A4 (Santa Cruz, sc-A0311), anti-actin (Santa Cruz, sc-1616), anti-tubulin (Sigma Aldrich, T-6074), anti-E6 (Santa Cruz, sc-365089). Chemiluminescent 
detection reagent was purchased from Millipore Spa (Luminata Classico and Forte Western HRP).

\section{Chromatin immunoprecipitation (ChIP)}

ChIPs were performed as previously described [17]. $4 \mu \mathrm{g}$ of the following antibodies were added to each IP and incubated overnight at $4^{\circ} \mathrm{C}$ : anti-NF-YA (Santa Cruz, sc-10779), anti-p53 (Santa Cruz, sc-126) and anti-IgG (Santa Cruz, sc-2027), used as control for non-specific interactions. Immunoprecipitated DNA was resuspended in TE buffer, and Real Time PCR analyses were performed with the following primers:

\begin{tabular}{|c|c|c|c|c|}
\hline Promoter & & 5'-3' Sequence & $\begin{array}{l}\text { bp } \\
\text { lenght }\end{array}$ & $\mathbf{T m}$ \\
\hline \multirow[t]{2}{*}{ Cdkn1a } & For & $\begin{array}{l}\text { ATTCCCCTAC } \\
\text { CCCATGCT }\end{array}$ & 153 & 60 \\
\hline & Rev & $\begin{array}{l}\text { GCCAGAAAG } \\
\text { CCAATCAGAG }\end{array}$ & & \\
\hline \multirow[t]{2}{*}{ Mdm2 P1 } & For & $\begin{array}{l}\text { CAGCCAAACC } \\
\text { CAAACATTCT }\end{array}$ & 184 & 56 \\
\hline & Rev & $\begin{array}{l}\text { CGCTGGAGT } \\
\text { TGTACCCAAAT }\end{array}$ & & \\
\hline \multirow[t]{2}{*}{ Mdm2 P2 } & For & $\begin{array}{l}\text { CAGGTAAGC } \\
\text { ACCGACTTGCT }\end{array}$ & 190 & 56 \\
\hline & Rev & $\begin{array}{l}\text { GCTGGAATCT } \\
\text { GTGAGGTGGT }\end{array}$ & & \\
\hline \multirow[t]{2}{*}{ Bax } & For & $\begin{array}{l}\text { CCCCCGTCACT } \\
\text { TTATCTGCT }\end{array}$ & 103 & 56 \\
\hline & Rev & $\begin{array}{l}\text { GGGTTCTAGGGG } \\
\text { ATCAGGAG }\end{array}$ & & \\
\hline \multirow[t]{2}{*}{ Puma } & For & $\begin{array}{l}\text { TCAGTGTGTGTG } \\
\text { TCCGACTGTC }\end{array}$ & 96 & 60 \\
\hline & Rev & $\begin{array}{l}\text { GGCAGGGC } \\
\text { CTAGCCCA }\end{array}$ & & \\
\hline \multirow[t]{2}{*}{$\begin{array}{l}\text { HPV18 } \\
\text { LCR }\end{array}$} & For & $\begin{array}{l}\text { CTCTTTGGC } \\
\text { GCATACAAGG }\end{array}$ & 90 & 60 \\
\hline & Rev & $\begin{array}{l}\text { GGGAGTGGA } \\
\text { TATAGTTGTGCAA }\end{array}$ & & \\
\hline \multirow[t]{2}{*}{ c-Myc } & For & $\begin{array}{l}\text { TATCTACACTAACAT } \\
\text { CCCACGCTCTG }\end{array}$ & 192 & 60 \\
\hline & Rev & $\begin{array}{l}\text { CATCCTTGTCCTGT } \\
\text { GAGTATAAATCATCG }\end{array}$ & & \\
\hline \multirow[t]{2}{*}{ CTRL- } & For & $\begin{array}{l}\text { TTCTCAACCTCA } \\
\text { GCACTGGTGACA }\end{array}$ & 248 & 60 \\
\hline & Rev & $\begin{array}{l}\text { GACTTTGCTGT } \\
\text { TTGCTGTCAGGCT }\end{array}$ & & \\
\hline
\end{tabular}

qRT-PCR assay

$2 \mu \mathrm{g}$ of the total RNA extracted from cells with RNeasy kit (Qiagen) was reversed transcribed with a Moloney murine leukemia virus reverse transcriptase (Promega Italia SrL, Milan, Italy) and subjected to qPCR with the following primers:

\begin{tabular}{|c|c|c|c|c|}
\hline Gene & & 5'-3' Sequence & $\begin{array}{l}\text { bp } \\
\text { lenght }\end{array}$ & $\mathbf{T m}$ \\
\hline \multirow[t]{2}{*}{ p53 } & For & $\begin{array}{l}\text { AAGGAAATTT } \\
\text { GCGTGTGGAGT }\end{array}$ & $218 / 223$ & 60 \\
\hline & Rev & $\begin{array}{l}\text { AAAGCTGT } \\
\text { TCCGTCCCAGTA }\end{array}$ & & \\
\hline \multirow[t]{2}{*}{ Ccnb1 } & For & $\begin{array}{l}\text { CACTTCCTTC } \\
\text { GGAGAGCATC }\end{array}$ & 240 & 60 \\
\hline & Rev & $\begin{array}{l}\text { CAGGTGCTG } \\
\text { CATAACTGGAA }\end{array}$ & & \\
\hline \multirow[t]{2}{*}{ Ccnb2 } & For & $\begin{array}{l}\text { CAGTTCCCAA } \\
\text { ATCCGAGAAA }\end{array}$ & 227 & 60 \\
\hline & Rev & $\begin{array}{l}\text { TCTGAGACAAG } \\
\text { CAGGAAGCA }\end{array}$ & & \\
\hline \multirow[t]{2}{*}{ TopoIIa } & For & $\begin{array}{l}\text { TGGCAGAGGC } \\
\text { AGAGAGAGTT }\end{array}$ & 82 & 60 \\
\hline & Rev & $\begin{array}{l}\text { TCAAAAAGCAC } \\
\text { CATAGAGTTGC }\end{array}$ & & \\
\hline \multirow[t]{2}{*}{$\mathrm{Cdc} 2$} & For & $\begin{array}{l}\text { CTGGGGTCAG } \\
\text { CTCGTTACTC }\end{array}$ & 172 & 60 \\
\hline & Rev & $\begin{array}{l}\text { ATTCCACTTC } \\
\text { TGGCCACACT }\end{array}$ & & \\
\hline \multirow[t]{2}{*}{$\begin{array}{l}\text { Mdm2 } \\
\text { P1 }\end{array}$} & For & $\begin{array}{l}\text { TTTCGCAGCC } \\
\text { AGGAGCACCGT }\end{array}$ & 268 & 60 \\
\hline & Rev & $\begin{array}{l}\text { GGGTCTCTT } \\
\text { GTTCCG }\end{array}$ & & \\
\hline \multirow[t]{2}{*}{$\begin{array}{l}\text { Mdm2 } \\
\text { P2 }\end{array}$} & For & $\begin{array}{l}\text { CTTTTTCTC } \\
\text { TGCTGATCCAG }\end{array}$ & 105 & 64 \\
\hline & Rev & $\begin{array}{l}\text { CAGGGTCTC } \\
\text { TTGTTCCGAAGCTG }\end{array}$ & & \\
\hline \multirow[t]{2}{*}{ Bax } & For & $\begin{array}{l}\text { GTCCGGGGAG } \\
\text { CAGCCCAGAG }\end{array}$ & 217 & 64 \\
\hline & Rev & $\begin{array}{l}\text { CTCCATGTTAC } \\
\text { TGTCCAGTTCGTCC }\end{array}$ & & \\
\hline \multirow[t]{3}{*}{ Puma } & For & $\begin{array}{l}\text { ACGACCTCAAC } \\
\text { GCACAGTACGAG }\end{array}$ & 145 & 64 \\
\hline & Rev & $\begin{array}{l}\text { TAATTGGGCTCC } \\
\text { ATCTCGGG }\end{array}$ & & \\
\hline & & & \multicolumn{2}{|c|}{ (Continued) } \\
\hline
\end{tabular}




\begin{tabular}{|c|c|c|c|c|}
\hline Gene & & 5'-3' Sequence & $\begin{array}{c}\text { bp } \\
\text { lenght }\end{array}$ & Tm \\
\hline \multirow[t]{2}{*}{ Cdkn1a } & For & $\begin{array}{l}\text { TGACCCTGAA } \\
\text { GTGAGCACAG }\end{array}$ & 183 & 60 \\
\hline & Rev & $\begin{array}{l}\text { GGGAAAAGGC } \\
\text { TCAACACTGA }\end{array}$ & & \\
\hline \multirow[t]{2}{*}{$\begin{array}{l}\text { HPV18 } \\
\text { E6 }\end{array}$} & For & $\begin{array}{l}\text { TAATAAGGTTG } \\
\text { CCTGCGGTGC }\end{array}$ & 161 & 60 \\
\hline & Rev & $\begin{array}{l}\text { TTCTCTGCGTC } \\
\text { GTTGGAGTC }\end{array}$ & & \\
\hline \multirow[t]{2}{*}{$\begin{array}{l}\text { HPV18 } \\
\text { E7 }\end{array}$} & For & $\begin{array}{l}\text { ACATTTACCA } \\
\text { GCCCGACGAG }\end{array}$ & 107 & 60 \\
\hline & Rev & $\begin{array}{l}\text { GGTCGTCTGCT } \\
\text { GAGCTTTCT }\end{array}$ & & \\
\hline \multirow[t]{2}{*}{ Jun } & For & $\begin{array}{l}\text { AGCAGCAAAG } \\
\text { AACTTTCCCG }\end{array}$ & 148 & 60 \\
\hline & Rev & $\begin{array}{l}\text { CGTCCTTCTT } \\
\text { CTCTTGCGTG }\end{array}$ & & \\
\hline \multirow[t]{2}{*}{ Jun B } & For & $\begin{array}{l}\text { TGGAACAGC } \\
\text { CCTTCTACCAC }\end{array}$ & 241 & 60 \\
\hline & Rev & $\begin{array}{l}\text { GAAGAGGCG } \\
\text { AGCTTGAGAGA }\end{array}$ & & \\
\hline \multirow[t]{2}{*}{ Fos } & For & $\begin{array}{l}\text { TTACTACCAC } \\
\text { TCACCCGCAG }\end{array}$ & 109 & 60 \\
\hline & Rev & $\begin{array}{l}\text { GACCGTGGGA } \\
\text { ATGAAGTTGG }\end{array}$ & & \\
\hline \multirow[t]{2}{*}{ E2F1 } & For & $\begin{array}{l}\text { ATGTTTTCCTG } \\
\text { TGCCCTGAG }\end{array}$ & 155 & 60 \\
\hline & Rev & $\begin{array}{l}\text { ATCTGTGGTG } \\
\text { AGGGATGAGG }\end{array}$ & & \\
\hline \multirow[t]{2}{*}{$\mathrm{cMyc}$} & For & $\begin{array}{l}\text { GAGGCTATTC } \\
\text { TGCCCATTTG }\end{array}$ & 120 & 60 \\
\hline & Rev & $\begin{array}{l}\text { GCTGCTGGTT } \\
\text { TTCCACTACC }\end{array}$ & & \\
\hline \multirow[t]{2}{*}{ Elk1 } & For & $\begin{array}{l}\text { CCACCTTCAC } \\
\text { CATCCAGTCT }\end{array}$ & 220 & 60 \\
\hline & Rev & $\begin{array}{l}\text { TCTTCCGAT } \\
\text { TTCAGGTTTGG }\end{array}$ & & \\
\hline \multirow[t]{2}{*}{ Sp1 } & For & $\begin{array}{l}\text { GAGAAAAC } \\
\text { AGCCCAGATGCC }\end{array}$ & 245 & 60 \\
\hline & Rev & $\begin{array}{l}\text { GCGTTTCCCA } \\
\text { CAGTATGACC }\end{array}$ & & \\
\hline \multirow[t]{2}{*}{ Rpl19 } & For & $\begin{array}{l}\text { ATGAGTATGC } \\
\text { TCAGGCTTCAGA }\end{array}$ & 376 & 60 \\
\hline & Rev & $\begin{array}{l}\text { TCAGGTACAGG } \\
\text { CTGTGATACA }\end{array}$ & & \\
\hline
\end{tabular}

\begin{tabular}{lrlcc}
\hline Gene & & \multicolumn{1}{c}{$\mathbf{5}^{\prime}-3$ ' Sequence } & $\begin{array}{c}\text { bp } \\
\text { lenght }\end{array}$ & Tm \\
\hline p63 & For & ACGAAGATC & 141 & 60 \\
& CCCAGATGATG & & \\
& Rev & TGCTGTTGCCT & & \\
& GTACGTTTC & & \\
p73 For & GCGTGGAAGGC & 185 & 60 \\
& & AATAATCTC & & \\
& Rev & CAGGGTGAT & & \\
& GATGATGAGGA & & \\
\hline
\end{tabular}

\section{Plasmids}

The wt PGL3-HPV18-URR luciferase plasmid was a kind gift from Dr. Dan DiMaio (Department of Genetics, Yale University School of Medicine, New Haven,USA) [32]. Mutated URR plasmids were obtained by introducing single point mutations through SOE (Splice by Overlap Extension)-PCR. Briefly, mutant promoters have been created through two rounds of PCR: in the first round, we used two internal primers, containing the desired mutations, coupled with external primers, containing the desired restriction sites (XhoI, HindIII), in order to obtain two half fragments of the promoter; in the the second round, we used the two fragments, obtained by the first PCR round, as internal primers coupled with two external primers, in order to obtain the complete promoter embedding the mutations.

\begin{tabular}{|c|c|c|c|}
\hline Mutation & Fragment & & Primer 5'-3' \\
\hline \multirow[t]{4}{*}{ Mut 1} & Fragment 1 & For & $\begin{array}{l}\text { TGAACAATGTG } \\
\text { CGCGCC }\end{array}$ \\
\hline & & $\begin{array}{l}\text { Rev } \\
\text { HindIII }\end{array}$ & $\begin{array}{l}\text { ATGCCAAGCTTA } \\
\text { CTTAGATCGC }\end{array}$ \\
\hline & Fragment 2 & For XhoI & $\begin{array}{l}\text { CCGGGCTC } \\
\text { GAGATCCC }\end{array}$ \\
\hline & & Rev & $\begin{array}{l}\text { GGCGCGCACA } \\
\text { TTGTTCA }\end{array}$ \\
\hline \multirow[t]{4}{*}{ Mut 2} & Fragment 1 & For & $\begin{array}{l}\text { ATTTTGAACA } \\
\text { CGGTTCG } \\
\text { CGCCTCTTTG } \\
\text { GCGCA }\end{array}$ \\
\hline & & $\begin{array}{l}\text { Rev } \\
\text { HindIII }\end{array}$ & $\begin{array}{l}\text { ATGCCAAGCTTAC } \\
\text { TTAGATCGC }\end{array}$ \\
\hline & Fragment 2 & For XhoI & $\begin{array}{l}\text { CCGGGCTCG } \\
\text { AGATCCC }\end{array}$ \\
\hline & & Rev & $\begin{array}{l}\text { AAGAGGCGCG } \\
\text { AACCGTG } \\
\text { TTCAAAATATG } \\
\text { TAGGAGCAGTG }\end{array}$ \\
\hline
\end{tabular}

(Continued) 


\begin{tabular}{|c|c|c|c|}
\hline Mutation & Fragment & & Primer 5'-3' \\
\hline \multirow[t]{4}{*}{ Mut 3} & Fragment 1 & For & $\begin{array}{l}\text { ATTTTGACTGATTGG } \\
\text { CCGGCCTCTTTGGCG } \\
\text { CATATAAG }\end{array}$ \\
\hline & & $\begin{array}{l}\text { Rev } \\
\text { HindIII }\end{array}$ & $\begin{array}{l}\text { ATGCCAAGCTT } \\
\text { ACTTAGATCGC }\end{array}$ \\
\hline & Fragment 2 & For XhoI & $\begin{array}{l}\text { CCGGGCTC } \\
\text { GAGATCCC }\end{array}$ \\
\hline & & Rev & $\begin{array}{l}\text { AAGAGGCCGGC } \\
\text { CAATCAGTCA } \\
\text { AAATATGTAG } \\
\text { GAGCAGTGCC }\end{array}$ \\
\hline \multirow[t]{4}{*}{ Mut 4} & Fragment 1 & For & $\begin{array}{l}\text { TAATTGCAT } \\
\text { ACGGTTCT } \\
\text { TGTACAACTACTTTC }\end{array}$ \\
\hline & & $\begin{array}{c}\text { Rev } \\
\text { HindIII }\end{array}$ & $\begin{array}{l}\text { ATGCCAAGCTTA } \\
\text { CTTAGATCGC }\end{array}$ \\
\hline & Fragment 2 & For XhoI & $\begin{array}{l}\text { CCGGGCTC } \\
\text { GAGATCCC }\end{array}$ \\
\hline & & Rev & $\begin{array}{l}\text { GTTGTACAA } \\
\text { GAACCGTA } \\
\text { TGCAATTAGCTTAAG }\end{array}$ \\
\hline
\end{tabular}

The obtained PCR fragments have been digested with XhoI and HindIII and cloned into the PGL3 luciferase plasmid. The mutated plasmids have been transformed in DH5 $\alpha$ Escherichia coli and then sequenced.

\section{Transient transfections}

The indicated plasmids were transfected into subconfluent Hela cells using Metafectene Pro (Biontex), according to the protocol provided by the manufacturer. Following 24 hours, cells were collected and lysed with transfection lysis buffer (1\% TritonX 100, 25 mM GlyGly pH 7.8, 15 mM MgSO4, 4 mM EGTA pH 8). Proteins quantification was performed with Bradford reagent (Sigma Aldrich) and luciferase activity was measured [41].

\section{Analysis of gene expression profiles}

Affymetrix gene expression profilings were performed in Hela cells before and after 72 hours from shCTR and shNF-YA infection (GeneChip ${ }^{\circledR}$ Human Genome U133 Plus 2.0). Raw data were retrieved from Geo Dataset GSE40215, published by Fleming et al. [25]. Biological replicates (triplicates) were grouped and processed: normalization ( $\mathrm{rma}$ ), quality controls, probe set filtering, finding differentially expressed probe sets and annotating those probe sets to gene symbols were performed using Bioconductor packages (Affy and Limma). Genes were defined as upregulated or downregulated when the fold change of shNF-YA versus shCTR profile was above 1.3 and FDR $<0.05$. KEGG analysis was performed using DAVID software with default settings.

\section{Statystical analysis}

At least three independent biological experiments have been performed. The values represented in the histograms are the average of the biological replicates and the bars indicate the Standard Error of the Mean (SEM). Statistical significance was calculated using independent, two tailed Student t-test between the indicated samples.

\section{ACKNOWLEDGMENTS}

We warmly thank Roberto Mantovani (University of Milan, Italy) and Susanna Molinari (University of Modena and Reggio Emilia, Italy) for precious suggestions and careful reading of the manuscript. We are indebted with Lawrence Banks (International Centre for Genetic Engineering and Biotechnology, Trieste, Italy) for the generous gift of C4-I cell line and Dan DiMaio (Department of Genetics, Yale University School of Medicine, New Haven, USA) for wt PGL3-HPV18-URR luciferase plasmid.

\section{CONFLICTS OF INTEREST}

The authors declare that there are no conflicts of interest.

\section{GRANT SUPPORT}

This work was supported by the Associazione Italiana per la Ricerca sul Cancro (AIRC) to CI (IG No. 14210).

\section{REFERENCES}

1. Bosch FX, Lorincz A, Munoz N, Meijer CJ, Shah KV. The causal relation between human papillomavirus and cervical cancer. J Clin Pathol. 2002; 55:244-65.

2. zur Hausen H. Papillomaviruses and cancer: from basic studies to clinical application. Nat Rev Cancer. 2002; 2:342-50.

3. Moody CA, Laimins LA. Human papillomavirus oncoproteins: pathways to transformation. Nat Rev Cancer. 2010; 10:550-60.

4. Hawley-Nelson P, Vousden KH, Hubbert NL, Lowy DR, Schiller JT. HPV16 E6 and E7 proteins cooperate to immortalize human foreskin keratinocytes. EMBO J. 1989; 8:3905-10.

5. Munger K, Phelps WC, Bubb V, Howley PM, Schlegel R. The E6 and E7 genes of the human papillomavirus type 16 together are necessary and sufficient for transformation of primary human keratinocytes. J Virol. 1989; 63:4417-21.

6. Dyson N, Howley PM, Munger K, Harlow E. The human papilloma virus-16 E7 oncoprotein is able to bind to the retinoblastoma gene product. Science. 1989; 243:934-7. 
7. Zerfass K, Schulze A, Spitkovsky D, Friedman V, Henglein B, Jansen-Durr P. Sequential activation of cyclin E and cyclin A gene expression by human papillomavirus type 16 E7 through sequences necessary for transformation. J Virol. 1995; 69:6389-99.

8. Scheffner M, Werness BA, Huibregtse JM, Levine AJ, Howley PM. The E6 oncoprotein encoded by human papillomavirus types 16 and 18 promotes the degradation of p53. Cell. 1990; 63:1129-36.

9. Thomas MC, Chiang CM. E6 oncoprotein represses p53-dependent gene activation via inhibition of protein acetylation independently of inducing p53 degradation. Mol Cell. 2005; 17:251-64.

10. Veldman T, Horikawa I, Barrett JC, Schlegel R. Transcriptional activation of the telomerase hTERT gene by human papillomavirus type 16 E6 oncoprotein. J Virol. 2001; 75:4467-72.

11. Oda H, Kumar S, Howley PM. Regulation of the Src family tyrosine kinase Blk through E6AP-mediated ubiquitination. Proc Natl Acad Sci U S A. 1999; 96:9557-62.

12. Thierry F. Transcriptional regulation of the papillomavirus oncogenes by cellular and viral transcription factors in cervical carcinoma. Virology. 2009; 384:375-9.

13. Sichero L, Sobrinho JS, Villa LL. Identification of novel cellular transcription factors that regulate early promoters of human papillomavirus types 18 and 16. J Infect Dis. 2012; 206:867-74.

14. Johannsen E, Lambert PF. Epigenetics of human papillomaviruses. Virology. 2013; 445:205-12.

15. Dolfini D, Gatta R, Mantovani R. NF-Y and the transcriptional activation of CCAAT promoters. Crit Rev Biochem Mol Biol. 2012; 47:29-49.

16. Imbriano C, Gnesutta N, Mantovani R. The NF-Y/p53 liaison: well beyond repression. Biochim Biophys Acta. 2012; 1825:131-9.

17. Benatti P, Dolfini D, Vigano A, Ravo M, Weisz A, Imbriano C. Specific inhibition of NF-Y subunits triggers different cell proliferation defects. Nucleic Acids Res. 2011; 39:5356-68.

18. Chae HD, Yun J, Shin DY. Transcription repression of a CCAAT-binding transcription factor CBF/HSP70 by p53. Exp Mol Med. 2005; 37:488-91.

19. Dalvai M, Mondesert O, Bourdon JC, Ducommun B, Dozier C. Cdc25B is negatively regulated by p53 through $\mathrm{Sp} 1$ and NF-Y transcription factors. Oncogene. 2011; 30:2282-8.

20. St Clair S, Giono L, Varmeh-Ziaie S, Resnick-Silverman L, Liu WJ, Padi A, Dastidar J, DaCosta A, Mattia M, Manfredi JJ. DNA damage-induced downregulation of Cdc25C is mediated by p53 via two independent mechanisms: one involves direct binding to the cde $25 \mathrm{C}$ promoter. Mol Cell. 2004; 16:725-36.

21. Imbriano C, Gurtner A, Cocchiarella F, Di Agostino S, Basile V, Gostissa M, Dobbelstein M, Del Sal G, Piaggio
G, Mantovani R. Direct p53 transcriptional repression: in vivo analysis of CCAAT-containing G2/M promoters. Mol Cell Biol. 2005; 25:3737-51.

22. Hung T, Wang Y, Lin MF, Koegel AK, Kotake Y, Grant GD, Horlings HM, Shah N, Umbricht C, Wang P, Kong B, Langerod,A, Borresen-Dale AL. et al. Extensive and coordinated transcription of noncoding RNAs within cellcycle promoters. Nat Genet. 2013; 43:621-9.

23. Puvvula PK, Desetty RD, Pineau P, Marchio A, Moon A, Dejean A, Bischof O. Long noncoding RNA PANDA and scaffold-attachment-factor SAFA control senescence entry and exit. Nat Commun. 2014; 5:5323.

24. Benatti P, Belluti S, Miotto B, Neusiedler J, Dolfini D, Drac M, Basile V, Schwob E, Mantovani R, Blow JJ, Imbriano C. Direct non transcriptional role of NF-Y in DNA replication. Biochim Biophys Acta. 2016; 1863:673-85.

25. Fleming JD, Pavesi G, Benatti P, Imbriano C, Mantovani R, Struhl K. NF-Y coassociates with FOS at promoters, enhancers, repetitive elements, and inactive chromatin regions, and is stereo-positioned with growth-controlling transcription factors. Genome Res. 2013; 23:1195-209.

26. Zambelli F, Pesole G, Pavesi G. Pscan: finding overrepresented transcription factor binding site motifs in sequences from co-regulated or co-expressed genes. Nucleic Acids Res. 2009; 37:W247-52.

27. Gurtner A, Fuschi P, Martelli F, Manni I, Artuso S, Simonte G, Ambrosino V, Antonini A, Folgiero V, Falcioni R, Sacchi A, Piaggio G. Transcription factor NF-Y induces apoptosis in cells expressing wild-type p53 through E2F1 upregulation and p53 activation. Cancer Res. 2010; 70:9711-20.

28. Kabe Y, Yamada J, Uga H, Yamaguchi Y, Wada T, Handa H. NF-Y is essential for the recruitment of RNA polymerase II and inducible transcription of several CCAAT boxcontaining genes. Mol Cell Biol. 2005; 25:512-22.

29. Elkon R, Linhart C, Sharan R, Shamir R, Shiloh Y. Genome-wide in silico identification of transcriptional regulators controlling the cell cycle in human cells. Genome Res. 2003; 13:773-80.

30. Barak Y, Gottlieb E, Juven-Gershon T, Oren M. Regulation of $\mathrm{mdm} 2$ expression by $\mathrm{p} 53$ : alternative promoters produce transcripts with nonidentical translation potential. Genes \& development. 1994; 8:1739-49.

31. Chen Z, Schiffman M, Herrero R, DeSalle R, Anastos K, Segondy M, Sahasrabuddhe VV, Gravitt PE, Hsing AW, Burk RD. Evolution and taxonomic classification of alphapapillomavirus 7 complete genomes: HPV18, HPV39, HPV45, HPV59, HPV68 and HPV70. PLoS One. 2013; 8:e72565.

32. Goodwin EC, Naeger LK, Breiding DE, Androphy EJ, DiMaio D. Transactivation-competent bovine papillomavirus E2 protein is specifically required for efficient repression of human papillomavirus oncogene expression and for acute growth inhibition of cervical carcinoma cell lines. J Virol. 1998; 72:3925-34. 
33. Mantovani R. A survey of 178 NF-Y binding CCAAT boxes. Nucleic Acids Res. 1998; 26:1135-43.

34. Soto U, Das BC, Lengert M, Finzer P, zur Hausen H, Rosl F. Conversion of HPV 18 positive non-tumorigenic HeLa-fibroblast hybrids to invasive growth involves loss of TNF-alpha mediated repression of viral transcription and modification of the AP-1 transcription complex. Oncogene. 1999; 18:3187-98.

35. Thierry F, Spyrou G, Yaniv M, Howley P. Two AP1 sites binding JunB are essential for human papillomavirus type 18 transcription in keratinocytes. J Virol. 1992; 66:3740-8.

36. Butz K, Hoppe-Seyler F. Transcriptional control of human papillomavirus (HPV) oncogene expression: composition of the HPV type 18 upstream regulatory region. J Virol. 1993; 67:6476-86.

37. Hietanen S, Lain S, Krausz E, Blattner C, Lane DP. Activation of p53 in cervical carcinoma cells by small molecules. Proc Natl Acad Sci U S A. 2000; 97:8501-6.

38. Saha B, Adhikary A, Ray P, Saha S, Chakraborty S, Mohanty S, Das, K, Mukherjee S, Mazumdar M, Lahiri L, Hossain DM, Sa G, Das T. Restoration of tumor suppressor p53 by differentially regulating pro- and anti-p53 networks in HPV18-infected cervical cancer cells. Oncogene. 2012; 31:173-86.

39. Kreis NN, Sanhaji M, Kramer A, Sommer K, Rodel F, Strebhardt K, Yuan J. Restoration of the tumor suppressor p53 by downregulating cyclin B1 in human papillomavirus 16/18-infected cancer cells. Oncogene. 2010; 29:5591-603.

40. Shamanna RA, Hoque M, Pe'ery T, Mathews MB. Induction of p53, p21 and apoptosis by silencing the NF90/ NF45 complex in human papilloma virus-transformed cervical carcinoma cells. Oncogene. 2013; 32:5176-85.

41. Benatti P, Basile V, Merico D, Fantoni LI, Tagliafico E, Imbriano C. A balance between NF-Y and p53 governs the pro- and anti-apoptotic transcriptional response. Nucleic Acids Res. 2008; 36:1415-28.

42. Xu H, Fu J, Ha SW, Ju D, Zheng J, Li L, Xie Y. The CCAAT box-binding transcription factor NF-Y regulates basal expression of human proteasome genes. Biochim Biophys Acta. 2012; 1823:818-25.

43. Lin Z, Nan Y, Zhang X, Zhao Y, Kim C, Kim I. Reverse transcription-polymerase chain reaction and western blotting analysis for detection of p63 isoforms in uterine cervical cancers. International journal of gynecological. 2006; 16:1643-7.

44. Okuyama T, Kurata S, Tomimori Y, Fukunishi N, Sato S, Osada M, Tsukinoki K, Jin, HF, Yamashita A, Ito M, Kobayashi S, Hata RI, Ikawa Y, Katoh I. p63(TP63) elicits strong trans-activation of the MFG-E8/lactadherin/BA46 gene through interactions between the TA and DeltaN isoforms. Oncogene. 2008; 27:308-17.

45. Romano RA, Birkaya B, Sinha S. Defining the regulatory elements in the proximal promoter of DeltaNp63 in keratinocytes: Potential roles for Sp1/Sp3, NF-Y, and p63. The Journal of investigative dermatology. 2006; 126:1469-79.
46. Seelan RS, Irwin M, van der Stoop P, Qian C, Kaelin WG, Jr., Liu W. The human p73 promoter: characterization and identification of functional E2F binding sites. Neoplasia. 2002; 4:195-203.

47. Kushnir AS, Davido DJ, Schaffer PA. Role of nuclear factor $\mathrm{Y}$ in stress-induced activation of the herpes simplex virus type 1 ICP0 promoter. J Virol. 2010; 84:188-200.

48. Chia MC, Leung A, Krushel T, Alajez NM, Lo KW, Busson P, Klamut HJ, Bastianutto C, Liu FF. Nuclear factor-Y and Epstein Barr virus in nasopharyngeal cancer. Clinical cancer research. 2008; 14:984-94.

49. Chang PJ, Wang SS, Chen LY, Hung CH, Huang HY, Shih YJ, Yen JB, Liou JY, Chen LW. ORF50-dependent and ORF50-independent activation of the ORF45 gene of Kaposi's sarcoma-associated herpesvirus. Virology. 2013; 442:38-50.

50. Gu Z, Plaza S, Perros M, Cziepluch C, Rommelaere J, Cornelis JJ. NF-Y controls transcription of the minute virus of mice $\mathrm{P} 4$ promoter through interaction with an unusual binding site. J Virol. 1995; 69:239-46.

51. Dolfini D, Zambelli F, Pavesi G, Mantovani R. A perspective of promoter architecture from the CCAAT box. Cell cycle. 2009; 8:4127-37.

52. Nardini M, Gnesutta N, Donati G, Gatta R, Forni C, Fossati A, Vonrhein C, Moras D, Romier C, Bolognesi M, Mantovani R. Sequence-specific transcription factor NF-Y displays histone-like DNA binding and H2B-like ubiquitination. Cell. 2013; 152:132-43.

53. Hochhauser D, Kotecha M, O'Hare C, Morris PJ, Hartley JM, Taherbhai Z, Harris D, Forni C, Mantovani R, Lee M, Hartley JA. Modulation of topoisomerase IIalpha expression by a DNA sequence-specific polyamide. Molecular cancer therapeutics. 2007; 6:346-54.

54. Kotecha M, Kluza J, Wells G, O'Hare CC, Forni C, Mantovani R, Howard P W, Morris P, Thurston DE, Hartley JA, Hochhauser D. Inhibition of DNA binding of the NF-Y transcription factor by the pyrrolobenzodiazepinepolyamide conjugate GWL-78. Molecular cancer therapeutics. 2008; 7:1319-28.

55. Yoshizawa S, Fujiwara K, Sugito K, Uekusa S, Kawashima H, Hoshi R, Watanabe Y, Hirano T, Furuya T, Masuko T, Ueno T, Fukuda N, Soma M et al. Pyrrole-imidazole polyamide-mediated silencing of KCNQ1OT1 expression induces cell death in Wilms' tumor cells. International journal of oncology. 2015; 47:115-21.

56. Mantovani F, Banks L. Inhibition of E6 induced degradation of $\mathrm{p} 53$ is not sufficient for stabilization of $\mathrm{p} 53$ protein in cervical tumour derived cell lines. Oncogene. 1999; 18:3309-15.

57. Belluti S, Basile V, Benatti P, Ferrari E, Marverti G, Imbriano C. Concurrent inhibition of enzymatic activity and NF-Y-mediated transcription of Topoisomerase-IIalpha by bis-DemethoxyCurcumin in cancer cells. Cell Death Dis. 2013; 4:e756. 